\title{
IDENTIFIKASI TINGKAT BAHAYA EROSI BERBASIS SISTEM INFORMASI GEOGRAFIS (SIG) PADA SUB DAERAH ALIRAN SUNGAI (DAS) RIAM KANAN
}

\section{IDENTIFICATION OF EROSION POTENTIAL BASED ON GEOGRAPHIC INFORMATION SYSTEMS (GIS) AT RIAM KANAN SUB WATERSHED}

\author{
Fransisca Dwiputri Giyanti ${ }^{1}$, Rony Riduan ${ }^{1}$ dan Ranti Aprilliantari ${ }^{1}$ \\ Program Studi Teknik Lingkungan, Fakultas Teknik UNLAM, Banjarbaru \\ Jalan A.Yani Km.36 Banjarbaru 70714 \\ Email : fransiez_sisca@yahoo.com; ronyrdn@gmail.com; ranti_psda@yahoo.com
}

\begin{abstract}
Abstrak
Salah satu faktor yang menyebabkan kondisi Sub DAS Riam Kanan di Kalimantan Selatan menjadi kritis adalah pembukaan lahan di sepanjang aliran sungai akibat penggunaan lahan oleh masyarakat yang tidak menerapkan teknik - teknik konservasi tanah yang tepat. Akibatnya fenomena kejadian banjir, tanah longsor, kekeringan dan pencemaran kualitas air akan meningkat apabila kondisi DAS tersebut tidak segera ditangani dengan upaya rehabilitasi lahan dan konservasi tanah. Tujuan penelitian ini untuk memetakan tingkat bahaya erosi di sepanjang Sun DAS Riam Kanan. Software ArcView GIS 3.3 adalah program yang berbasis SIG yang dirancang untuk mengumpulkan, menyimpan, dan menganalisa objek - objek serta fenomena - fenomena dimana lokasi geografis merupakan karakteristik yang penting untuk dianalisis sehingga dapat mempermudah proses visualisasi dan eksplorasi geografis dari data sekunder yang diperoleh khususnya dalam mengidentifikasi tingkat bahaya erosi pada wilayah studi Sub DAS Riam Kanan ini. Hasil penelitian menunjukkan di sepanjang Sub DAS Riam Kanan teridentifikasi tingkat bahaya erosi kriteria ringan dengan luas $120.590,81$ ha $(73,19 \%)$, kriteria sedang seluas $34.859,34$ ha $(21,16 \%)$, dan kriteria sangat berat seluas 9318,00 ha $(5,66 \%)$.
\end{abstract}

Kata kunci: erosi, konservasi, kritis, lahan, rehabilitasi, sistem informasi geografis

\begin{abstract}
Riam Kanan Sub Watershed is one of the Sub Watersheds that has a critical condition in South Kalimantan. One of the factors that cause the Riam Kanan Sub Watershed condition became critical was land opening along the river due to the use of land by people who did not apply the appropriate soil conservation techniques. Due to the critical condition of the watershed, the phenomenon of floods, landslides, and droughts and water pollution will increase if the condition is not treated immediately by land rehabilitation and soil conservation. Software ArcView GIS 3.3 is a GIS-based program that is designed to collect, store, and analyze objects and phenomena where geographic location is an important characteristic for analysis to ease the visualization and geograph exploration process from secondary data to identify erosion potential of the study area Riam Kanan Sub Watershed.Research showed that along Riam Kanan Sub Watershed, 120.590,81 ha (73,19\%) of the area was identified to possessed light, 34859.34 ha (21.16\%) had midde Ohazard erosion rate and 9318.00 ha $(5.66 \%)$ experienced severehazard errosion rate.
\end{abstract}

Keywords: conservation, critical, erosion, geographic information systems, land, rehabilitation, 


\section{PENDAHULUAN}

Kekritisan lahan pada suatu Daerah Aliran Sungai merupakan suatu kondisi yang ditunjukkan oleh rendahnya kesuburan tanah karena lapisan tanah atas (top soil) telah hilang. Padahal lapisan ini digunakan sebagai media bagi micro flora dan micro fauna untuk tumbuh. Hilangnya sebagian besar lapisan tanah ini disebabkan oleh erosi (Heung et al. 2013). Erosi tanah merupakan proses penghancuran agregatagregat tanah menjadi fraksi yang halus dan dipindahkan oleh air aliran permukaan dari tempat terjadi penghancuran tersebut ke tempat lain (Aprisal dan Junaidi, 2010). Untuk melihat kekritisan suatu lahan dapat ditunjukkan oleh besarnya erosi yang terjadi (Sismanto, 2009). Salah satu faktor yang mempengaruhi erosi adalah besarnya curah hujan (Weng et al., 2011; Dahal dan Hasegawa, 2008), karakteristik tanah, iklim lokal dan tata guna lahan (Alkharabsheh et al., 2013).

Balai Pengelolaan Daerah Aliran Sungai (BPDAS) Barito di Kalimantan Selatan mencatat kondisi kritis daerah aliran sungai terjadi pada 13 Daerah Aliran Sungai yang ada di wilayah Kalimantan Selatan, terbesar pada DAS Barito, DAS Riam Kanan serta DAS Riam Kiwa. Pada Tahun 2006 tercatat laju erosi yang terjadi pada Sub DAS Riam Kanan sebesar 20.051.659 ton/th (BPDAS Barito, 2009), sehingga mengakibatkan intensitas bencana semakin meningkat.

Sub DAS Riam Kanan merupakan salah satu bagian dari DAS Barito Kabupaten Banjar Kalimantan Selatan. Sub DAS Riam Kanan merupakan salah satu Sub DAS yang memiliki kondisi kritis di Kalimantan Selatan (BPDAS Barito, 2009). Salah satu faktor yang menyebabkan kondisi Sub DAS Riam Kanan menjadi kritis adalah karena terbukanya lahan di sepanjang aliran sungai akibat penggunaan lahan yang tidak sesuai. Fenomena kejadian banjir, tanah longsor, dan kekeringan serta pencemaran kualitas air beberapa tahun terakhir menunjukkan peningkatan. Hal ini mengindikasikan telah terjadi gangguan keseimbangan siklus hidrologi di daerah aliran sungai. Upaya konservasi DAS harus diawali dengan penetapan daerah kritis, yang nantinya digunakan sebagai acuan untuk penetapan daerah - daerah prioritas penanganan, untuk meminimisasi terjadinya bencana.

Salah satu indikator untuk mengetahui tingkat kekritisan suatu DAS adalah besarnya erosi yang terjadi pada DAS tersebut. Rumusan yang dapat dipergunakan untuk memprediksi besarnya erosi adalah model yang dikembangkan oleh Wischmeier dan Smith (1978) yaitu Universal Soil Loss Equation (USLE) yang merupakan metode paling populer dan banyak digunakan untuk memprediksi besarnya erosi (Modica et al., 2004; As-syakur, 2008). USLE adalah suatu model erosi yang dirancang untuk memprediksi rata - rata erosi jangka panjang dari erosi lembar (sheet erosion) termasuk di dalamnya erosi alur (rill erosion) pada suatu keadaan tertentu. Erosi yang terjadi selanjutnya dihitung pada masing - masing unit lahan, dilajutkan dengan perhitungan laju rata rata erosi dari suatu bidang tanah tertentu.

Sistem Informasi Geografis (SIG) dirancang untuk mengumpulkan, menyimpan, dan menganalisa objek - objek serta fenomena fenomena dimana lokasi geografis merupakan karakteristik yang penting untuk dianalisis (Tunas, 2005; Arsyad, 2010). Sistem Informasi Geografis dapat mempermudah proses visualisasi dan eksplorasi geografis dari data sekunder yang diperoleh khususnya dalam mengidentifikasi tingkat bahaya erosi pada wilayah studi Sub DAS Riam Kanan ini. Penelitian ini menggunakan Sistem Informasi Geografis untuk memetakan tingkat kekritisan lahan di sepanjang Sub DAS Riam Kanan.

\section{METODA}

\section{Analisa Hidrologi \\ Curah Hujan Rerata Daerah}

Pada studi ini luas Sub DAS Riam Kanan yang dikaji memiliki luas permukaan sungai sebesar $164.768,15$ ha yang terdiri dari 8 (delapan) 
daerah tangkapan air yaitu Hajawa, Kalaan, Kayutangi, Lulut, Riam Kanan Hilir, Mandiangin, Sekitar Waduk, dan Tanjungan, serta dipengaruhi oleh 3 (tiga) stasiun penakar hujan, sehingga dalam hal ini dipakai metode rata - rata aljabar untuk mendapatkan besaran curah hujan rerata daerah sekitar Sub DAS Riam Kanan. Rumus rata-rata hujan daerah yang digunakan adalah sebagai berikut:

$$
\begin{aligned}
& d=\frac{d_{1}+d_{2}+d_{3}+\ldots+d_{n}}{n}=\sum_{i=1}^{n} \frac{d_{i}}{n} \ldots \ldots \ldots \ldots . \\
& \text { dengan : } \\
& \mathrm{d}=\text { = tinggi curah hujan rata-rata daerah } \\
& \mathrm{d}_{1}, \mathrm{~d}_{2}, . . \mathrm{d}_{\mathrm{n}}=\text { tinggi curah hujan pada pos penakar } \\
& 1,2, . . \mathrm{n} \\
& \mathrm{n}=\text { banyaknya pos penakar }
\end{aligned}
$$

\section{Hujan Rancangan Log Pearson Type III}

Untuk menentukan curah hujan rancangan dengan metode Log Pearson Type III, data curah hujan harian maksimum yang telah urut ditransformasikan kedalam bentuk logaritma untuk mendapatkan besaran simpangan baku dan koefisien kemencengan yang akan di gunakan dalam menentukan besaran analisis data curah hujan maksimum pada kala tahun yang diinginkan sebagai acuan debit curah hujan harian maksimum dan minimum yang mungkin terjadi pada wilayah studi yaitu Sub DAS Riam Kanan.

\section{Penggambaran Kondisi Sub DAS Riam Kanan}

\section{Penentuan Batas DAS}

Sebelum melakukan analisa laju erosi dan usaha konservasi, perlu dilakukan identifikasi wilayah yang akan dikaji. Kajian dapat dilakukan berdasarkan wilayah administrasi atau berdasarkan konsep daerah aliran sungai. Pada studi ini, wilayah yang dikaji menggunakan konsep daerah aliran sungai mengingat segala peristiwa yang berhubungan dengan degradasi lingkungan, dalam hal ini erosi, berlangsung menurut batas - batas daerah aliran sungai, sehingga sangat diperlukan untuk menentukan batas DAS sebagai wilayah kajian.

Pada studi ini, dalam melakukan penentuan batas DAS menggunakan bantuan software ArcView GIS 3.3. Dalam menentukan batas DAS pada ArcView GIS 3.3 dibutuhkan beberapa extension sebagai alat bantu antara lain GeoProcessing Wizard, Spatial Analyst, dan 3D Analyst.

\section{Penggambaran Peta Kelas Kemiringan Lereng}

Data ini diperlukan untuk mengetahui kelas kemampuan lahan yang ada di daerah studi. Kelas kemiringan lereng pada Sub DAS Riam Kanan dibagi menjadi 4 kelas, yaitu 0-8\%, 8 $15 \%, 15-25 \%, 25-40 \%$ dan $>40 \%$. Kemiringan lahan ini dapat dilihat pada Gambar 1.

\section{Analisa Laju Erosi \\ Penentuan Indeks Erosivitas (R)}

Perhitungan indeks erosivitas pada studi ini menggunakan metode yang dikemukakan oleh Bols. Untuk menghitung indeks erosivitas hujan dengan metode Bols diperlukan data curah hujan bulanan, data jumlah hari hujan per bulan, dan data hujan maksimum harian (24 jam). Rumus yang digunakan untuk menentukan indeks erosi hujan bulanan adalah sebagai berikut:

$$
E I_{30}=6,119 P_{b}^{1,211} \cdot N^{-0.474} \cdot P_{\max }^{0,526}
$$

dengan :

$\mathrm{EI}_{30}=$ Indeks erosi hujan bulanan $(\mathrm{KJ} / \mathrm{ha})$

$\mathrm{P}_{\mathrm{b}}=$ Curah hujan bulanan $(\mathrm{cm})$

$\mathrm{N}=$ Jumlah hari hujan per bulan

$\mathrm{P}_{\max }=$ Hujan maksimum harian (24 jam) dalam bulan yang bersangkutan $(\mathrm{cm})$.

\section{Perhitungan Laju Erosi (A)}

Perhitungan laju erosi lahan dihitung untuk setiap unit lahan yang memiliki informasi tata guna lahan, kemiringan lereng, dan jenis tanah. Untuk mendapatkan unit lahan dilakukan dengan cara menggabungkan (overlay) dari peta yang telah dibuat sebelumnya, yaitu peta 


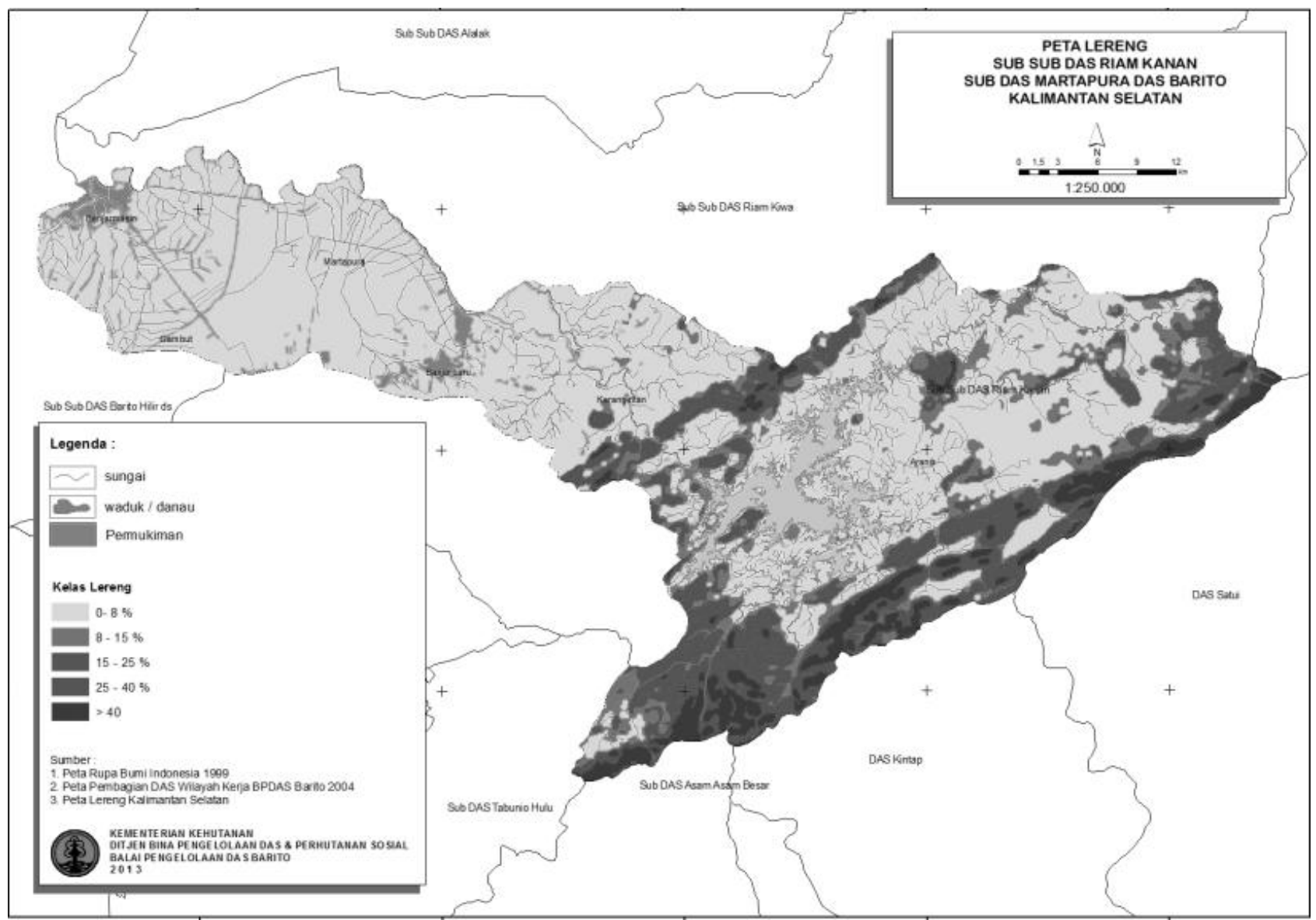

Gambar 1. Peta Kemiringan Lereng Sub DAS Riam Kanan

kemiringan lereng, peta jenis tanah, dan peta tata guna lahan. Kemudian ditambahkan atribut dari hasil perhitungan indeks erosivitas hujan, sehingga di dapatkan nilai kristis lahan.

\section{Kalibrasi Data Erosi}

Reaktor yang digunakan pada kalibrasi ini berbentuk kotak persegi dengan dimensi $1 \mathrm{~m}$ x 1 $\mathrm{m} \times 0,2 \mathrm{~m}$, sehingga dapat dengan maksimal menampung tanah yang tererosi pada saat hujan. Dari hasil kalibrasi data di lapangan, didapatkan data primer sebagai berikut :

- Indeks erosivitas hujan $(\mathrm{R})=1827,66$ $\mathrm{KJ} / \mathrm{ha}$.th (berdasarkan data 10 tahun terakhir).

- Indeks erodibilitas $(\mathrm{K})=0,29$ ton $/ \mathrm{KJ}$ (berdasarkan data nilai indeks $\mathrm{K}$ untuk tanah latosol).
- Indeks faktor panjang dan kemiringan lereng $(\mathrm{LS})=6,8$ (berdasarkan pengamatan

- kemiringan lereng pada lokasi sampling, yaitu $\geq 40 \%$ ).

- Indeks faktor pengelolaan tanaman (C) = 0,30 (berdasarkan hasil pengamatan langsung pada lokasi sampling).

- Indeks pengelolaan lahan $(\mathrm{P})=1,00$ (berdasarkan tidak adanya tindakan konservasi pada lokasi sampling).

- Berat volume sampel tanah yang tererosi = $340 \mathrm{gr} / \mathrm{m}^{3}$.

Berdasarkan data hasil kalibrasi tersebut, maka dapat dihitung besaran laju erosi yang terjadi pada lokasi sampling dengan menggunakan persamaan model USLE, sebagai berikut :

$$
\mathrm{A}=\text { R.K.LS.C.P }
$$


Pola Rehabilitasi Lahan dan Konservasi Tanah (RLKT)

\section{Arahan Penggunaan Lahan}

Arahan penggunaan lahan pada studi ini mengacu pada SK Mentan No. 837/Kpts/II/1980. Arahan penggunaan lahan tersebut disesuaikan dengan fungsi kawasan yang ditetapkan berdasarkan kriteria dan tata cara penetapan hutan lindung dan hutan produksi. Arahan tersebut berdasarkan pada karakteristik fisik DAS sebagai berikut ((Alkharabsheh et al., 2013) :

1. Kemiringan lereng

2. Jenis tanah menurut kepekaannya terhadap erosi

3. Curah hujan harian rata-rata

Ketiga faktor tersebut kemudian dinilai dengan skoring dan penetapan klasifikasi penggunaan lahan dengan menjumlahkan skor ketiga faktor tersebut.

\section{HASIL DAN PEMBAHASAN}

\section{Analisa Hidrologi}

\section{Curah Hujan Rerata Daerah}

Hasil perhitungan curah hujan rerata daerah ini di dapatkan curah hujan maksimal rerata daerah terbesar pada tahun 2003 yaitu sebesar 181,17 mm dan terkecil terjadi pada tahun 2000 yaitu sebesar $66,330 \mathrm{~mm}$.

\section{Hujan Rancangan Log Pearson Type III}

Pada perhitungan curah hujan rancangan Log Pearson Type III ini di dapatkan curah hujan rancangan minimum yaitu pada kala tahun 1 (satu) sebesar 65,0674 mm dan maksimum pada kala tahun 100 (seratus) yaitu sebesar 233,33 $\mathrm{mm}$.

\section{Uji Kesesuaian Distribusi}

Pada uji kesesuaian distribusi menggunakan metode uji Smirnov - Kolmogorof. Berdasarkan uji ini didapatkan kesimpulan bahwa data curah hujan pada Sub DAS Riam Kanan terdistribusi normal, sehingga data curah hujan tersebut dapat dijadikan acuan dalam menentukan indeks erosivitas lahan wilayah studi.

\section{Uji Chi Square}

Uji Chi Square dilakukan untuk memperoleh curah hujan rencana maksimum dan minimum. Pada uji Chi Square ini didapatkan nilai curah hujan rancangan minimum sebesar $71,863 \mathrm{~mm}$ dan maksimum sebesar 99,742 mm.

\section{Penggambaran Peta Jenis Tanah}

Berdasarkan data dari BPDAS Barito yang telah dianalisa, jenis tanah dominan pada Sub DAS Riam Kanan adalah tanah latosol. Pada studi ini, tekstur tanah ditentukan berdasarkan jenis tanahnya. Sedangkan nilai - nilai K dan tingkat erodibilitas diperkirakan dengan melihat peta serta merujuk pada Tabel 1.

Tabel 1. Data Jenis Tanah Sub DAS Riam Kanan

\begin{tabular}{|c|c|c|c|}
\hline No & Jenis Tanah & $\mathbf{K}$ & $\begin{array}{c}\text { Luas } \\
\text { (ha) }\end{array}$ \\
\hline 1. & Alluvial & 0,24 & 14.577 .16 \\
\hline 2. & $\begin{array}{l}\text { Komplek Podsolik } \\
\text { Merah - Kuning, } \\
\text { Latosol \& Litosol }\end{array}$ & 29 & $18.298,99$ \\
\hline 3. & $\begin{array}{l}\text { Komplek Podsolik } \\
\text { Merah - Kuning, } \\
\text { Laterik }\end{array}$ & 0,29 & $15.526,21$ \\
\hline 4. & Latosol & 0,29 & $71.792,84$ \\
\hline 5. & Organosol Gleihumus & 0,23 & $36.176,85$ \\
\hline
\end{tabular}

Sumber : BPDAS Barito, 2009

\section{Penggambaran Peta Kelas Kemiringan Lereng}

Sebagian besar pada Sub DAS Riam Kanan, terutama di bagian hulunya memiliki kemiringan lereng yang agak curam, bahkan sampai sangat curam, yaitu di atas $40 \%$. Hal ini disebabkan karena banyak terdapat tebing sungai atau lembah antara punggung gunung. 
Semakin besar kemiringan lereng maka semakin besar pula kemungkinan untuk terjadi erosi. Oleh karena itu erosi rentan terjadi pada daerah Sub DAS Riam Kanan yang memiliki kemiringan lereng sebesar $25-40 \%$, dan $>40$ $\%$. Apalagi jika daerah ini dimanfaatkan untuk berbagai aktifitas masyarakat, maka kemungkinan terjadi erosi semakin bertambah besar.

\section{Penggambaran Peta Tata Guna Lahan}

Peta tata guna lahan dapat dilihat pada Gambar 2. Penggambaran peta tata guna lahan ini adalah berdasarkan peta dari Badan Koordinasi Survei dan Pemetaan Nasional (BAKOSURTANAL). Peta ini diperoleh dari BP-DAS Barito, yang melakukan pengukuran pada tahun 2009.

\section{Analisa Laju Erosi \\ Penentuan Indeks Erosivitas (R)}

Indeks erosivitas hujan tahunan merupakan hasil dari penjumlahan indeks erosivitas hujan bulanan. Pada wilayah studi Sub DAS Riam Kanan ini memiliki indeks erosivitas (R) sebesar 1827,66 KJ/ha.

\section{Penentuan Indeks Erodibilitas (K)}

Indek erodibilitas (K), digunakan berdasarkan hasil penyelidikan erodibilitas tanah pada Sub DAS Riam Kanan yang pernah dilakukan oleh Balai Pengelolaan Daerah Aliran Sungai (BPDAS) Barito.

\section{Penentuan Faktor Panjang dan Kemiringan Lereng (LS)}

Kemiringan lereng juga merupakan salah satu faktor yang berpengaruh terhadap terjadinya erosi, karena semakin meningkatnya persentase (\%) kemiringan suatu lereng, maka erosi yang terjadi akan semakin besar. Jika di lihat pada peta kelas kemiringan lereng (Gambar 1), daerah yang memiliki kemiringan lereng yang agak curam berada pada wilayah kecamatan Aranio, yang pada studi ini merupakan daerah hulu dari Sub DAS Riam Kanan.
Selanjutnya nilai LS diperoleh berdasarkan penelitian yang pernah dilakukan oleh Balai Pengelolaan DAS Barito, seperti yang dapat dilihat pada Tabel 2.

Tabel 2. Nilai Faktor LS pada Sub DAS Riam Kanan

\begin{tabular}{cc}
\hline Kemiringan & Nilai LS \\
\hline $0-8 \%$ & 0,4 \\
$8-15 \%$ & 1,4 \\
$15-25 \%$ & 3,1 \\
$25-40 \%$ & 6,8 \\
$>40 \%$ & 9,5 \\
\hline Sumber : BPDAS Barito, 2009.
\end{tabular}

Dari Tabel 2 menunjukkan kemiringan di atas $40 \%$, mempunyai nilai LS sebesar 9,5.

\section{Penentuan Nilai Tanaman dan Konservasi Tanah (CP)}

Pada studi ini, nilai $\mathrm{C}$ dan $\mathrm{P}$ ditentukan berdasarkan hasil penelitian yang pernah dilakukan oleh BPDAS Barito pada Sub DAS Riam Kanan. Pada wilayah studi Sub DAS Riam Kanan, tutupan lahan yang rentan mengakibatkan terjadinya erosi adalah pertambangan, perkebunan, tegalan, dan belukar yang ada pada wilayah Sub DAS dengan kemiringan lereng di atas $8 \%$.

\section{Perhitungan Laju Erosi (A)}

Besaran dari laju erosi hasil perhitungan pada wilayah studi dapat dilihat pada Tabel 3. Laju erosi terbesar terdapat pada Riam kanan, yaitu sebesar 30.938.413 ton/tahun. Pada tahun 2006 laju erosi total pada Sub DAS Riam Kanan yang di teliti oleh BPDAS Barito adalah sebesar 20.051.659 ton/thn, sehingga dapat disimpulkan bahwa laju erosi total pada lahan Sub DAS Riam Kanan mengalami peningkatan. Hal ini terjadi disebabkan oleh tingginya curah hujan yang menyebabkan indeks erosivitas pada Sub DAS Riam Kanan menjadi relatif besar. Faktor lain disebabkan oleh jenis tanah pada Sub DAS Riam Kanan yang didominasi oleh tanah latosol yang relatif peka terhadap erosi (Alkharabsheh et al., 2013). 


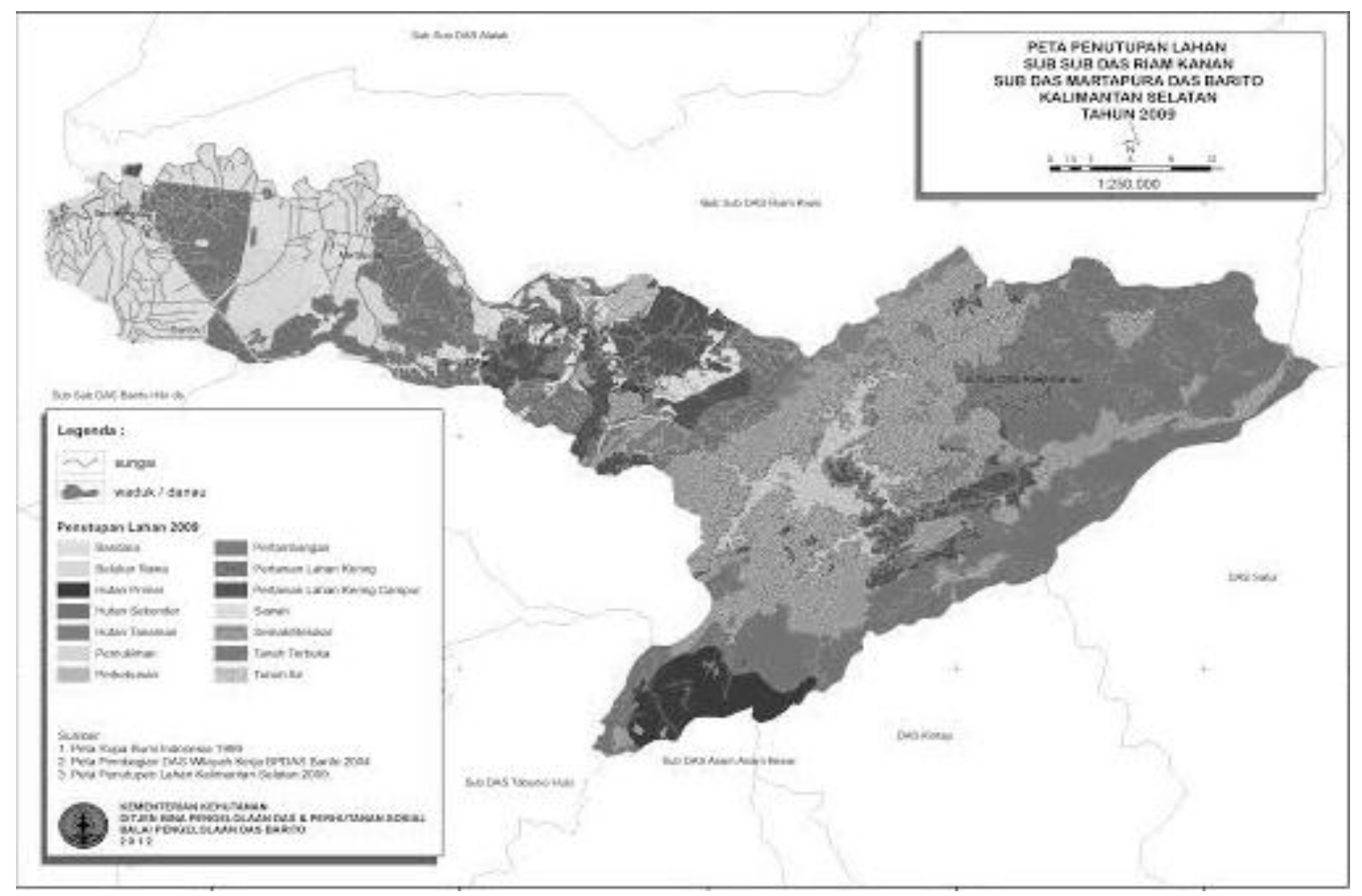

Gambar 2. Peta Tata Guna Lahan Sub DAS Riam Kanan

Faktor lain yang menyebabkan meningkatnya laju erosi pada Sub DAS Riam Kanan adalah terbukanya lahan di sepanjang aliran sungai akibat penggunaan lahan oleh masyarakat yang tidak menerapkan teknik - teknik konservasi tanah yang tepat. Menurut Alkharabsheh et al. (2013), pengelolaan penggunaan tanah ikut menentukan tingkat erosi.

\section{Kalibrasi Data Erosi}

Lokasi pengambilan sampel kalibrasi ini berada pada lokasi penambangan batu di kecamatan Aranio, dengan kemiringan lereng $\geq 40 \%$ dan penutup lahan berupa belukar. Lokasi tersebut dipilih dikarenakan kondisi geografis kecamatan Aranio yang terdiri dari tebing dengan kemiringan rata - rata $\geq 40 \%$ dan penutupan lahan sebagian besar terdiri dari semak belukar dan hutan serta berjenis tanah latosol. Selain itu, kecamatan Aranio memang telah teridentifikasi memiliki laju erosi yang cukup tinggi. Oleh karena itu lokasi tersebut dinilai dapat mewakili perhitungan laju erosi dari keseluruhan wilayah pada Sub DAS Riam Kanan. Dengan berat volume tanah $=340 \mathrm{gr} / \mathrm{m}^{3}$, maka didapatkan nilai kehilangan tanah pada lokasi sampling adalah sebesar $=\frac{1081,24}{340}=3,18 \mathrm{~m} / \mathrm{thn}$.

Hal ini menjelaskan bahwa erosi yang terjadi pada lokasi sampling cukup besar dikarenakan kemiringan lereng yang cukup curam $(\geq 40 \%)$, dan terbukanya lahan lokasi sampling untuk penambangan batu serta tidak adanya tindakan konservasi pada lahan tersebut.

\section{Analisa Kekritisan Lahan}

\section{Analisa Tingkat Bahaya Erosi}

Berdasarkan hasil perhitungan dan analisa, kondisi tingkat bahaya erosi yang terjadi pada Sub DAS Riam Kanan berada pada kriteria ringan, sedang dan sangat berat. Luas lahan Sub DAS Riam Kanan yang teridentifikasi tingkat bahaya erosi kriteria ringan tersebar di 
Tabel 3. Rekapitulasi Besaran Laju Erosi Pada Sub DAS Riam Kanan

\begin{tabular}{lrrr}
\hline \multirow{2}{*}{ DTA } & \multirow{2}{*}{ Luas (ha) } & \multicolumn{2}{c}{ Erosi } \\
\cline { 3 - 4 } & & (ton/ha.thn) & (ton/thn) \\
\hline Hajawa & $31.936,40$ & 149,34 & $4.769 .356,12$ \\
Kalaan & $15.739,56$ & 27,65 & $435.135,61$ \\
Kayutangi & $22.863,66$ & 106,96 & $2.445 .431,11$ \\
Lulut & $20.600,17$ & 111,93 & $2.305 .758,35$ \\
Riam Kanan Hilir & $13.662,91$ & 495,31 & $6.767 .308,98$ \\
Mandiangin & $12.580,21$ & 247,71 & $3.116 .289,02$ \\
Sekitar Waduk & $33.335,62$ & 304,08 & $10.136 .849,09$ \\
Tanjungan & $14.049,62$ & 68,49 & $962.285,48$ \\
\hline Total & $164.768,15$ & $1.511,47$ & $30.938 .413,77$ \\
\hline
\end{tabular}

sepanjang Sub DAS Riam Kanan dengan luas $120.590,81$ ha $(73,19 \%)$. Kriteria sedang seluas $34.859,34$ ha $(21,16 \%)$, dan kriteria sangat berat seluas $9.318,00$ ha $(5,66 \%)$.

Tingkat bahaya erosi di pengaruhi oleh berbagai faktor, antara lain faktor alam, faktor geologi dan faktor biologis. Faktor - faktor alam yang mempengaruhi tingkat bahaya erosi adalah erodibilitas tanah dan intensitas hujan. Adapun faktor geologi meliputi jenis tanah dan kemiringan lahan. Sedangkan faktor biologis meliputi tutupan vegetasi lahan dan tata guna lahan oleh manusia.

Beberapa desa yang memiliki tingkat bahaya erosi dengan kriteria sangat berat, wajib menjadi daerah prioritas. Desa - desa tersebut antara lain adalah Desa Artain, Aranio dan Pinggiran Hulu. Hal ini disebabkan karena berubahnya tata guna lahan pada desa - desa tersebut yang diakibatkan oleh penggunaan lahan yang tidak menerapkan teknik - teknik konservasi tanah secara tepat. Sebagai contoh, lahan yang seharusnya tetap berfungsi sebagai hutan berubah menjadi lahan tambang ilegal di sepanjang kaki pegunungan Meratus yang lokasinya berada pada bagian hulu Sub DAS Riam Kanan.

\section{Penentuan Lahan Kritis}

Berdasarkan hasil analisa penetuan tingkat kekritisan lahan, dapat diambil kesimpulan bahwa pada wilayah Sub DAS Riam Kanan sebagian besar (73\%) merupakan lahan

potensial kritis yang sebagian besar berada di daerah tangkapan air Kalaan, Kayutangi, Lulut dan Mandiangin. Sedangkan wilayah Sub DAS Riam Kanan yang merupakan lahan kritis (6\%) berada pada Desa Artain, Aranio dan Pinggiran Hulu yang memang telah dianalisi dan teridentifikasi memiliki tingkat bahaya erosi sangat berat.

Pada lahan - lahan yang termasuk kriteria lahan potensial kritis dan semi kritis, jika tidak dilakukan tindakan konservasi tanah yang tepat, dapat menyebabkan terjadinya erosi sehingga lahan akan menjadi kritis. Pada lahan - lahan yang termasuk kriteria kritis dan sangat kritis sangat perlu untuk dilakukan rehabilitasi lahan dan tindakan konservasi tanah yang tepat sehingga dapat menurunkan laju erosi yang terjadi.

\section{Pola Rehabilitasi Lahan dan Konservasi Tanah (RLKT) Arahan Penggunaan Lahan}

Berdasarkan hasil skoring dan overlay peta jenis tanah, intensitas hujan, dan kemiringan lereng, dapat ditetapkan empat arahan penggunaan lahan sesuai dengan fungsinya, yaitu :

- Kawasan lindung seluas 9.886,09 ha (6\%)

- Kawasan penyangga seluas 28.010,59 ha $(17 \%)$ 
- Kawasan budidaya tanaman tahunan seluas 4.6135,08 ha (28\%)

- Kawasan budidaya tanaman musiman seluas $8.0736,69$ ha $(49 \%)$

Dengan demikian dapat disimpulkan bahwa sebagian besar lahan pada Sub DAS Riam Kanan dapat dimanfaatkan sebagai kawasan budidaya tanaman musiman. Rekapitulasi arahan fungsi kawasan Sub DAS Riam Kanan dapat dilihat pada Tabel 4 .

Tabel 4. Rekapitulasi Arahan Fungsi Kawasan Sub DAS Riam Kanan

\begin{tabular}{lrr}
\hline \multicolumn{1}{c}{ Arahan Fungsi Kawasan } & \multicolumn{1}{c}{ \% } & \multicolumn{1}{c}{ Luas (ha) } \\
\hline Kawasan Lindung & 6 & $9.886,09$ \\
Kawasan Penyangga & 17 & $28.010,59$ \\
$\begin{array}{l}\text { KawasanBudidaya Tanaman } \\
\text { Tahunan }\end{array}$ & 28 & $46.135,08$ \\
$\begin{array}{l}\text { Kawasan BudidayaTanaman } \\
\text { Musiman }\end{array}$ & 49 & $80.736,39$ \\
\hline Total & 100 & $164.768,15$ \\
\hline
\end{tabular}

\section{Arahan Rehabilitasi Lahan dan Konservasi Tanah (ARLKT)}

Berdasarkan hasil dari klasifikasi fungsi kawasan, dapat dilakukan tindakan rehabilitasi lahan dan konservasi tanah pada Sub DAS Riam Kanan antara lain sebagai berikut :

- Pada kawasan lindung dapat dilakukan reboisasi pada lahan semak belukar dan reklamasi lahan.

- Pada kawasan penyangga dapat dilakukan pertanaman dalam strip, tumpangsari, pembuatan teras, bertanam menurut kontur pada lahan tegalan dan perkebunan.

- Pada kawasan budidaya tanaman tahunan dapat dilakukan penanaman tanaman penutup tanah sedang (berupa semak) pada lahan belukar, bertanam menurut kontur, pertanaman dalam strip, dan tumpang sari pada lahan tegalan dan perkebunan.

- Pada kawasan budidaya tanaman semusim dapat dilakukan penanaman menurut kontur dan pembuatan teras pada lahan sawah dan tegalan.

\section{KESIMPULAN}

Berdasarkan hasil klasifikasi fungsi kawasan, dapat dilakukan tindakan rehabilitasi lahan dan konservasi tanah pada Sub DAS Riam Kanan antara lain: pada kawasan lindung dapat dilakukan reboisasi pada lahan semak belukar dan reklamasi lahan; pada kawasan penyangga dapat dilakukan pertanaman dalam strip, tumpangsari, pembuatan teras, bertanam

menurut kontur pada lahan tegalan dan perkebunan; pada kawasan budidaya tanaman tahunan dapat dilakukan penanaman tanaman penutup tanah sedang berupa semak; pada lahan belukar, bertanam menurut kontur, pertanaman dalam strip, dan tumpang sari pada lahan tegalan dan perkebunan; dan pada kawasan budidaya tanaman semusim dapat dilakukan penanaman menurut kontur serta pembuatan teras pada lahan sawah dan tegalan.

\section{DAFTAR PUSTAKA}

Alkharabsheh M. M., AlexandridisT.K., Bilas G., Misopolinos N. dan Silleos N. 2013. Impact of land cover change on soil erosion hazard in northern Jordan using remote sensing and GIS, Procedia Environmental Sciences, 19: 912 - 921.

Aprisal dan Junaidi. 2010. Prediksi Erosi dan Sedimentasi Pada Berbagai Penggunaan Lahan di Sub DAS Danau Limau Manis Pada DAS Kuranji Kota Padang, J-Solum, 7(1) : 1829-7994.

Arsyad, S. 2010. Konservasi Tanah dan Air. Bogor : IPB Press.

As-syakur, A. R.. 2008. Prediksi Erosi Dengan Menggunakan Metode USLE dan Sistem Informasi Geografis (SIG) Berbasis Piksel di Daerah Tangkapan Air Danau Buyan. Prosiding PIT MAPIN XVII, Bandung. 
Dahal R. K. dan Hasegawa, S. 2008 Representative rainfall thresholds for landslides in the Nepal Himalaya, Geomorphology, 100:429-443.

Heung B., Bakker L., Schmidt M. G., 2013. Modelling the dynamics of soil redistribution induced by sheet erosion using the Universal Soil Loss Equation and cellular automata Dragićević S. Geoderma, 202-203: 112-125.

Kinnell., P.I.A. 2008. The Miscalculation of The USLE Topographic Factors in GIS. Faculty of Science University of Canberra. Canberra Australia.

Laen, J.M. and W.C. Moldenhauer. 2003. Pioneering Soil Erosion Prediction: The USLE Story.Special Publication No. 1. World Association of Soiland Water Conservation. Department of Soil and Water Conservation Ministry of Water Resources. Beijing-China

Modica A.E.C., Nearing M.A., dan Santoro V.C. 2004. Scale Effect in USLE and WEPP Application for Soil Erosion Computation from Three Sicilian Basins. Journal of Hydrology, 293: 100114

Prahasta, E. 2005. Konsep-Konsep Dasar Sistem Informasi Geografis. Bandung: Informatika.

Sismanto. 2009. Analisa Lahan Kritis Sub DAS Riam Kanan DAS Barit, Jurnal Aplikasi, 6(1) : 1907-753X.

Tunas, I Gede. 2005. Prediksi Erosi Lahan DAS Bengkulu Dengan Sistem Informasi Geografis (SIG), Jurnal SMARTek, 3(3) : 137-145.

Weng Meng-Chia, Wu Min-Hao, Ning ShuKuang, Jou Yeun-Wen. 2011. Evaluating triggering and causative factors of landslides in Lawnon River Basin, Taiwan, Engineering Geology 123: 72-82. 